Revista Destaques Acadêmicos, Lajeado, v. 9, n. 2, 2017. ISSN 2176-3070 DOI: http://dx.doi.org/10.22410/issn.2176-3070.v9i2a2017.1294 www.univates.br/revistas

\title{
A FUNÇÃO COMPLEMENTAR DA PREVIDÊNCIA PRIVADA FRENTE AO REGIME GERAL DA PREVIDÊNCIA SOCIAL
}

\author{
Ana Paula Backes Conte ${ }^{1}$, Fernanda Pinheiro Brod ${ }^{2}$
}

Resumo: Não restam dúvidas sobre a importância da seguridade social para o Brasil, uma vez que conforme a própria Constituição de 1988 dispõe, ela constitui um significativo instrumento de proteção social à disposição dos cidadãos, compreendendo um conjunto integrado de ações que partem de iniciativas dos poderes públicos e da sociedade, com a finalidade de assegurar os direitos relativos à previdência social, à saúde e à assistência social. Assim, verifica-se que a seguridade social é muito abrangente, pois se destina a auxiliar a todos que dela necessitem, desde que haja expressa previsão legal. Porém, especificadamente sobre a previdência social, sabe-se que ela nem sempre é suficiente para manter um determinado padrão de vida e arcar com todas as despesas que as pessoas possuem. Nesse sentido, este artigo tem por objetivo analisar de forma geral a previdência complementar privada. Privilégio para poucos, a previdência complementar privada tem o principal intuito de complementar os ganhos auferidos com a previdência pública. Portanto, pretende-se fazer um breve levantamento de suas principais características, bem como demonstrar a sua função frente aos rendimentos obtidos através da previdência pública. Trata-se de pesquisa qualitativa, realizada por meio de método dedutivo e de procedimento técnico bibliográfico, onde as reflexões partem de noções gerais sobre a seguridade social, para posteriormente adentrar na previdência social e, especificadamente, na previdência complementar privada, elencando a evolução histórica; o conceito; os objetivos e suas principais características, para, em seguida, analisar-se a sua função e importância diante da previdência pública, concluindo-se ser ela uma alternativa para o cidadão que possui condições financeiras de complementar seus rendimentos, propiciando segurança para seu futuro e de sua família.

Palavras-chave: Seguridade Social. Previdência Social. Previdência Complementar Privada.

1 Bacharela em Direito pelo Centro Universitário UNIVATES, de Lajeado/RS. Advogada. anabackes@universo.univates.br.

2 Doutora em Direito pela PUCRS. Mestre em Direito pela UNISC. Professora na Univates. Advogada. 


\section{INTRODUÇÃO}

No Brasil, a seguridade social tem um papel fundamental, uma vez que constitui um significativo instrumento de proteção social à disposição do cidadão, pois assegura e reconhece a assistência social, a previdência social e a saúde. Especificadamente sobre a previdência social e a consequente concessão de benefícios previdenciários, sabe-se que muitas vezes o valor auferido pelas pessoas não é suficiente para custear todas as despesas do dia a dia e nem prover tranquilidade financeira.

Assim, não há dúvidas sobre a preocupação das pessoas em relação às incertezas futuras, pois o sentimento de insegurança permeia a todos. Diante de tal sentimento que remete a uma possível insuficiência de valores para arcar com os custos de vida, há, muitas vezes, a necessidade de as pessoas complementarem a renda auferida na previdência pública, o que pode ser feito através da previdência complementar. Consequentemente, este tipo de previdência acaba adquirindo maior visibilidade e relevância socioeconômica.

Nesse viés, entende-se que as pessoas buscam durante a sua existência um determinado padrão de vida e, por isso, acabam optando por outros meios/alternativas no sentido de complementar os rendimentos provenientes dos benefícios recebidos da previdência social. Para tanto, muitas contratam um plano de previdência complementar, pois acreditam que servirá como suplementação ao valor auferido pela previdência pública, garantindo não só o seu próprio futuro, como de sua família.

Ocorre que, infelizmente, nem todas as pessoas possuem condições financeiras de poder contratar um plano de previdência complementar para garantia de equilíbrio e tranquilidade financeira, ademais, isso é um privilégio para poucos. Por isso, o sistema da seguridade social é considerado de extrema importância, uma vez que é formado por políticas sociais de assistência social, saúde e previdência social, que tem como princípio fundamental garantir amparo ao cidadão necessitado em situações como desemprego, doença ou velhice.

Salienta-se ainda que apesar de a seguridade social integrar três vertentes, a saber, a saúde; a assistência social e a previdência social, este trabalho tem como finalidade entender especificadamente a previdência privada, sendo esta integrante do sistema de seguridade social. Porém, é importante frisar que pelo fato de a previdência privada possuir caráter complementar frente ao regime geral da previdência social, estas categorias devem ser analisadas de forma conjunta.

\section{ASPECTOS HISTÓRICOS DA SEGURIDADE SOCIAL E DA PREVIDÊNCIA SOCIAL NO BRASIL}

Dentro do contexto ora abordado, é de fundamental importância trazer ao presente estudo, mesmo que de forma breve, a evolução histórica do tema no 
país. Para tanto, através dos relatos da origem da seguridade social no Brasil, bem como do surgimento da previdência social e também da previdência complementar, com a citação de datas e marcos, é possível ter a dimensão das conquistas previdenciárias alcançadas durante o passar dos tempos.

\subsection{Origem da Seguridade Social no Brasil}

Historicamente, o cenário de desigualdades e injustiças sociais fez com que paulatinamente as preocupações inerentes aos mais necessitados passassem a merecer mais atenção. Dessa forma, para que os indivíduos alcançassem os direitos fundamentais que hoje possuem, o caminho foi longo e árduo.

Sarlet $(2009$, p. 35) informa que os direitos fundamentais "[...] nascem e se desenvolvem com as Constituições nas quais foram reconhecidos e assegurados [...]".

Para tanto, dentro de uma abordagem histórica, é importante mencionar, mesmo brevemente, que o Estado Liberal, "[...] ocasionou uma série de avanços e benefícios para a sociedade, eis que propiciou um desenvolvimento econômico muito grande (dando condições para a revolução industrial), houve uma valorização do indivíduo [...]" (ARALDI JUNIOR, 2010, texto digital).

Salienta ainda o autor que "[...] com o passar do tempo, o individualismo pregado pelo Estado Liberal extrapolou, gerando comportamentos egoístas e competitivos entre as pessoas, que acabaram esquecendo do ente social coletivo [...]" (ARALDI JUNIOR, 2010, texto digital).

Assim, acaba surgindo o Estado Social que foi "[...] compelido a adotar políticas públicas destinadas à melhoria das condições de vida dos mais pobres, especialmente da classe trabalhadora, como forma de compensar as desigualdades originadas pelos novos modos de produção" (LEITE, 2011, p. 148-149).

Com as diferenças existentes entre o Estado Liberal e o Estado Social, surge o Estado Democrático de Direito que, conforme Morais (1996, p. 74-75):

[...] tem um conteúdotransformador da realidade, nãose restringindo, como o Estado Social de Direito, a uma adaptação melhorada das condições sociais de existência. Assim, o seu conteúdo ultrapassa o aspecto material de concretização de uma vida digna ao homem e, passa a agir simbolicamente como fomentador da participação pública quando o democrático qualifica o Estado, que irradia os valores da democracia sobre os seus elementos constitutivos e, pois, também sobre a ordem jurídica.

Portanto, pode-se dizer que "[...] o Estado Democrático de Direito tem por objetivos fundamentais a construção de uma sociedade mais livre, justa e solidária, a correção das desigualdades sociais e regionais, a promoção do bemestar e justiça sociais [...]" (LEITE, 2011, p. 150). 
O Brasil acabou se firmando como um Estado Democrático de Direito, pois estabeleceu em sua Constituição de 1988 uma base de direitos de ordem social. Ademais, os direitos de ordem social visam garantir condições de igualdade para que os indivíduos possam ter uma vida digna através de garantias e proteções dadas pelo estado de direito, ou seja, parte-se do pressuposto do bem-estar social de todos.

Assim, nestes direitos, podemos enquadrar a seguridade social, uma vez que ela "[...] é instrumento de bem-estar. É, também, redutor das desigualdades sociais causadas pela falta de ingressos financeiros no orçamento do indivíduo e de sua família, e instrumento de justiça social" (SANTOS, 2016, p. 14).

No Brasil, mesmo havendo divergências quanto às origens da seguridade social, informa Tavares (2005), que as primeiras preocupações inerentes à seguridade social ocorreram através das santas casas de misericórdia, destacando a de Santos (1543), montepios e sociedades beneficentes, sendo que todas possuíam cunho particular e mutualista.

Já no ano de 1824, diante da primeira Constituição do Brasil, Santos (2015) relata que a mesma, através do disposto em seu artigo 179, §31, passou a garantir os socorros públicos. Ademais, enfatiza que foi nesta Constituição que a assistência pública foi prevista no Brasil.

Em relação à Constituição de 1891, salienta-se que ela foi muito importante, uma vez que:

[...] foi a primeira a conter a expressão 'aposentadoria'. Determinou que a 'aposentadoria só poderá ser dada aos funcionários públicos em caso de invalidez no serviço da Nação' (art. 75). Na verdade, o benefício era realmente dado, pois não havia nenhuma fonte de contribuição para o financiamento de tal valor (MARTINS, 2004, p. 32).

Posteriormente, outro marco que merece destaque é a Lei ${ }^{\circ} 3.724$ de 15 de janeiro de 1919, pois segundo Martins (2004, p. 33), a mesma:

[...] tornou obrigatório pagamento de indenização pelos empregadores em decorrência dos acidentes do trabalho sofridos por seus empregados. Estabeleceu, ainda, o seguro para acidentes do trabalho. O seguro não era pago à Previdência Social, mas a empresas privadas.

Após esta lei, frisa-se a criação do Decreto Legislativo $n^{\circ} 4.682$, de 24 de janeiro de 1923, decreto este mais conhecido como Lei Eloy Chaves. Conforme Castro e Lazzari (2014), para a doutrina majoritária e para a legislação nacional, esta lei ficou conhecida como marco inicial da Previdência Social no Brasil, criando as Caixas de Aposentadorias e Pensões para os ferroviários, mediante contribuições dos trabalhadores. 
Ainda, destacam Castro e Lazzari (2014) que após a criação da Lei Eloy Chaves, surgiram outras Caixas com diferentes ramos da atividade econômica. Outra informação de suma importância trazida pelos autores é a de que "[...] a primeira crise do sistema previdenciário ocorreria em 1930. Em face de inúmeras fraudes e denúncias de corrupção, o governo de Getúlio Vargas suspendeu, por seis meses, a concessão de qualquer aposentadoria" (p. 40).

Diante dessas fraudes e denúncias de corrupção, "[...] passou a estrutura, pouco a pouco, a ser reunida por categoria profissional, surgindo os IAP Institutos de Aposentadoria e Pensões (dos Marítimos, dos Comerciários, dos Bancários, dos Empregados em Transportes de Carga" (CASTRO; LAZZARI, 2014, p. 40).

Já na Carta Magna de 1934, Correia e Correia (2013) informam que ficava a cargo dos Estados-Membros a fiscalização das leis sociais, bem como cuidar das assistências públicas e da saúde. Ainda, esta Constituição estabeleceu a competência da União para que a mesma fixasse regras de assistência social.

Em 1937 houve a outorga de uma nova Constituição, sendo que, segundo os mesmos doutrinadores, pouco inovou em relação aos direitos sociais, limitando-se à instituição de seguros de velhice, casos de acidentes do trabalho e invalidez. Também estabeleceu alguns deveres das associações de trabalhadores, no sentido de prestar assistência no que se refere aos seguros sociais e seguros de acidentes do trabalho.

No que tange à Constituição de 1946, é relevante destacar que:

[...] previa normas sobre previdência no capítulo que versava sobre Direitos Sociais, obrigando, a partir de então, o empregador a manter seguro de acidentes de trabalho. Foi a primeira tentativa de sistematização constitucional de normas de âmbito social, elencadas no art. 157 do texto. A expressão 'previdência social' foi empregada pela primeira vez numa Constituição brasileira (CASTRO; LAZZARI, 2014, p. 42).

Salienta-se que no período de vigência da Carta Magna acima referida, “[...] ocorreu a fusão de todas as CAP's de ferroviários e serviços públicos, originando a CAPFESP Caixa de Aposentadorias e Pensões dos Ferroviários e Empregados dos Serviços Públicos [...]" (LIMA, 2013, texto digital).

Outro marco significativo para o presente estudo é a criação da Lei ${ }^{\circ}$ 3.807, de 26 de agosto de 1960, mais conhecida como Lei Orgânica da Previdência Social - LOPS, regulamentada pelo Decreto $\mathrm{n}^{\circ} 48.959$, pois, conforme Lima (2013, texto digital) “[...] padronizou o sistema assistencial, ampliando benefícios, instituindo o auxílio-natalidade, auxílio-funeral, o auxílio reclusão e estendeu a assistência para outras categorias profissionais [...]".

A Constituição de 1967 e sua Emenda n ${ }^{\circ}$ 1, de 1969, não inovaram em relação à matéria previdenciária. Ademais, "[...] a Emenda apenas teria 
disposto de forma um pouco mais minuciosa a respeito de vários benefícios previdenciários (salário-família, proteção à gestante após o parto, proteção à velhice, invalidez, em casos de morte e desemprego etc.) [...]" (CORREIA; CORREIA, 2013, p. 26).

Assim, após o breve relato sobre as principais alterações ocorridas nas Constituições, bem como sobre a criação de algumas importantes leis, finalmente temos o panorama da Constituição de 1988, que, segundo Correia e Correia (2013, p. 26), “[...] foi bastante minuciosa no tratamento da questão da seguridade social. Do mesmo modo, significativas alterações foram promovidas no tema pela Emenda Constitucional n. 20, de 1998".

Martins (2004) destaca que na Carta Magna de 1988, passaram a fazer parte do gênero seguridade social, além da saúde, a assistência social e a previdência social.

Além disso, Correia e Correia (2013, p. 26-27) enfatizam que nesta Constituição foi criado um capítulo próprio para a seguridade social:

[...] Nesses dispositivos encontra-se desde o conceito de seguridade social até a forma básica do custeio e dos benefícios previdenciários alcançados. Versa-se, ainda, sobre a saúde e a assistência social. Trata-se de ampla normatização a respeito da matéria securitária, como jamais vislumbrado em qualquer ordem constitucional.

Deste modo, pode-se concluir que "[...] a Seguridade Social calcada na Carta Magna de 88 constitui avanço extraordinário na redução das profundas desigualdades sociais [...]" (SILVA, 2012, texto digital).

Em relação à Emenda Constitucional n. 20, de 1998, informa-se que "[...] Uma das grandes novidades introduzidas nessa Emenda ficou por conta da concepção da aposentadoria, observado o tempo de contribuição e não mais apenas o tempo de serviço [...]." (CORREIA; CORREIA, 2013, p. 27).

Também, destaca-se que, "atualmente, a matéria previdenciária é regida principalmente pelas Leis n. 8.212/91 (relativa ao custeio) e 8.213/91 (referente aos benefícios), regulamentadas pelo Decreto n. 3.048, de 6 de maio de 1999 [...]" (CORREIA; CORREIA, 2013, p. 28).

Embora a Carta Magna de 1988 tenha previsto aos cidadãos avanços significativos em relação aos direitos sociais, no momento atual em que o país se encontra, onde seriam necessárias por parte do governo políticas públicas eficientes que pudessem minimizar os efeitos das desigualdades sociais, a situação é totalmente inversa, o que pode ser comprovado através da Proposta de Emenda à Constituição $n^{\circ}$ 287/2016, proposta esta que vem sendo almejada pelo governo e tem como objetivo a reforma da previdência. Em consulta ao site oficial da Câmara dos Deputados no dia 20 de fevereiro de 2017, tal proposta aguarda o parecer do relator na Comissão Especial. Portanto, se por um lado há a alegação de que a previdência social causa um rombo aos cofres 
públicos (principal argumento do governo atual), é preciso enfatizar que com esta reforma estarão sendo suprimidos direitos fundamentais garantidos pela Constituição de 1988, conquistas históricas conforme brevemente narrado acima. Ademais, seus proponentes ignoram o lado positivo da previdência social, destacando, por exemplo, que por conta de sua expansão, acabou por auxiliar boa parte da população mais pobre no Brasil. Portanto, pela importância e seriedade do assunto, certamente ele ainda irá render uma série de debates, discussões e estudos.

Nesta senda, mesmo que de forma breve, considerou-se de extrema importância apresentar não só as origens da seguridade social no Brasil, mas também um breve panorama atual uma vez que o seu cenário é muito dinâmico, e por isso, exige um acompanhamento das constantes mudanças legislativas pelas quais passou e vem passando. Caso aprovada a reforma previdenciária nos moldes em que está sendo proposta, a temática da previdência complementar assumirá papel ainda mais relevante.

\subsection{O surgimento da Previdência Social no Brasil}

Conforme Ramos (2005, p. 16), “a previdência social, no modelo constitucional anterior a 1988, era considerada gênero que tinha como espécies a previdência social propriamente dita, a assistência social e a saúde".

Assim, "[...] suas manifestações encontravam espaço na filantropia, por meio das Santas Casas de Misericórdia [...]" (RAMOS, 2005, p. 16).

Nesse sentido, Goes (2015, p. 01) informa que, "no Brasil, as primeiras formas de proteção social deram-se através das Santas Casas de Misericórdia, sendo a de Santos a mais antiga, fundada em 1543 [...]".

Porém, salienta o mesmo autor que "[...] considera-se como marco inicial da Previdência Social brasileira a Lei Eloy Chaves (1923)" (GOES, 2015, p. 01). Este também é o entendimento de Correia e Correia (2013, p. 27), dispondo que "[...] o grande marco do direito previdenciário brasileiro foi, em 1923, a Lei Eloy Chaves, que instituía a primeira Caixa de Aposentadoria e Pensões para os trabalhadores da iniciativa privada $[. . .]^{\prime \prime}$.

Sobre esta lei é de se dizer que ela acabou instituindo para os ferroviários Caixas de Aposentadoria e Pensões. Além disso, "[...] assegurava, para esses trabalhadores, os benefícios de aposentadoria por invalidez, aposentadoria ordinária (equivalente à atual aposentadoria por tempo de contribuição), pensão por morte e assistência médica [...]" (GOES, 2015, p. 01).

Portanto, "[...] a Lei Eloy Chaves ficou conhecida como marco inicial da Previdência Social Brasileira devido ao desenvolvimento e à estrutura que a previdência passou a ter depois do seu advento" (GOES, 2015, p. 02).

Hoje, pode-se dizer que o sistema de previdência social, de maneira ampla e objetiva, "[...] é obrigatório à população economicamente ativa, 
mediante o adimplemento de contribuições e atendimento dos demais requisitos determinados na lei para o percebimento dos benefícios nele previstos" (RAMOS, 2005, p. 14).

\subsection{O surgimento da Previdência Complementar Privada no Brasil}

Primeiramente, destaca-se que a previdência privada foi introduzida no Brasil através dos fundos de pensão e dos montepios. Nesse sentido, aponta Ramos (2005, p. 23) que:

A previdência privada surgiu no Brasil, pela primeira vez, já com as características de facultatividade e mutualismo, em 10 de janeiro de 1835, por meio do Mongeral - Montepio Geral de Economia dos Servidores do Estado, que se traduziu em uma entidade aberta de previdência sem fins lucrativos.

Portanto, o Montepio Geral de Economia dos Servidores do Estado (MONGERAL) “[...] foi a primeira instituição modelada de forma a complementar a renda dos trabalhadores quando da inatividade" (WEINTRAUB, 2003, p. 05).

Weintraub (2003) destaca também a importância da Lei $n^{\circ} 294$, de 05 de setembro de 1895, que fora regulamentada pelo Decreto $\mathrm{n}^{\circ} 2.153$, de 01 de novembro de 1895, pois trazia em sua base o cunho fiscalizatório sobre as entidades seguradoras. Já o Decreto $\mathrm{n}^{\circ} 4.270$, de 10 de dezembro de 1901, acabou regulando, de uma forma geral, os mecanismos de seguros no Brasil. Destaca o autor que essas, de maneira ampla, foram as bases da criação da previdência privada, pois acabaram permitindo a fortificação da securitização privada.

Nesta senda, Weintraub (2003) enfatiza que efetivamente, até o ano de 1977, não havia no Brasil previsões legais específicas sobre a previdência privada, assim, "[...] a falta de legislação refletia a existência exígua de mercado. Não houve, até 1977, a necessidade do legislador de se preocupar com a regulamentação de um sistema minimamente difundido [...]" (WEINTRAUB, 2003, p. 06).

Ademais, sobre o assunto, Nascimento apud Correia e Villela (2004, p. 55) informa que:

Na esfera constitucional o regime de previdência privada foi expressamente disciplinado apenas com a edição da vigente Constituição Federal, mais especificadamente com a Emenda Constitucional n. 20, de 15.12.1998, pela qual foi alterada a redação original dos arts. 201 e 202 da CF/ 88.

Nesse sentido, observa-se a importância do artigo 202 da Constituição Federal de 1988, pois o mesmo determinou "[...] as principais características do regime de previdência privada, estabelecendo o caráter complementar e 
autônomo de tal regime em relação ao geral, observada a facultatividade de ingresso e a constituição de reservas [...]" (NASCIMENTO apud CORREIA; VILLELA, 2004, p. 55-56).

Também é relevante informar, dentro do contexto abordado, que "a lei complementar n. 109 remodelou a Previdência Privada, primando por conferir transparência e maior flexibilidade aos planos de benefícios, visando ensejar mudanças que viabilizem o crescimento do sistema privado de previdência [...]" (WEINTRAUB, 2003, p. 07).

Portanto, através dos aspectos abordados, resta evidenciado que a previdência complementar acabou surgindo "[...] da premente necessidade de estabilidade social, ou seja, introduziu formas de garantia da manutenção da qualidade de vida de camadas sociais cujas rendas são superiores ao teto determinado na previdência pública [...]" (RAMOS, 2005, p. 107).

\section{CONCEITO E CARACTERÍSTICAS DA PREVIDÊNCIA COMPLEMENTAR PRIVADA}

Para o presente estudo, é relevante abordarmos não só o conceito de previdência complementar privada, mas também elencarmos as suas principais características, uma vez que tendo tais aspectos definidos de forma clara e objetiva, poder-se-á ter uma maior compreensão sobre o tema ora estudado.

\subsection{Conceito de Previdência Complementar Privada}

Em relação ao conceito de previdência privada, Weintraub (2003, p. 05) destaca que:

A palavra previdência é proveniente do latim praevidentia, no sentido de prever, antever. A palavra privada consiste etimologicamente no feminismo substantivado do adjetivo privado, que por sua vez é oriundo do latim privatu; privus, e tem um significado de particular, que não é público (grifos do autor).

Já para Póvoas (2007, p. 103), a expressão "previdência privada" conhecida no Brasil, é puramente brasileira e "[...] objetivou identificar facilmente a instituição que, em relação ao domínio previdenciário geral, ocupa ou pode ocupar os espaços vazios deixados pela previdência social, em termos de satisfação das necessidades previdenciárias".

Castro e Lazzari (2014, p. 106) destacam o artigo $2^{\circ}$ da Lei Complementar $n^{\circ} 109 / 2001$, onde salientam que "entende-se por entidades de previdência privada 'as que têm por objetivo principal instituir e executar planos privados de benefícios de caráter previdenciário [...]"”.

Por fim, Ramos (2005, p. 22), enfatiza que "o próprio trabalhador, pelo seu esforço pessoal, com o intuito de garantir a sua qualidade de vida, busca 
a complementação da sua aposentadoria, efetuando poupança prévia durante sua vida laborativa, acumulando valores".

\subsection{Características da Previdência Complementar Privada}

Primeiramente, insta frisar que o artigo 201 da Constituição Federal de 1988 regulamenta o Regime Geral de Previdência Social, já, o artigo 202, com a redação dada pela Emenda Constitucional n ${ }^{\circ} 20$ de 1998, trata especificadamente da previdência privada. Desta forma, verifica-se que a previdência privada está inserida na previdência social, porém, não se pode confundir tais regimes, uma vez que cada um possui características peculiares.

Para tanto, o caput do artigo 202 da Constituição Federal de 1988, com redação dada pela Emenda Constitucional n ${ }^{\circ} 20$ de 1998, dispõe que:

Art. 202. O regime de previdência privada, de caráter complementar e organizado de forma autônoma em relação ao regime geral de previdência social, será facultativo, baseado na constituição de reservas que garantam o benefício contratado, e regulado por lei complementar. (Redação dada pela Emenda Constitucional $n^{\circ} 20$, de 1998) (Vide Emenda Constitucional n 20, de 1998) (texto digital).

Assim, "o regime de previdência privada tem, então, as seguintes características: caráter complementar, autonomia em relação ao RGPS; facultatividade; constituição de reservas e disciplina por lei complementar" (SANTOS, 2015, p. 577).

Sobre a característica de complementaridade é de se dizer que "a previdência privada se destina justamente a cobrir a diferença necessária para que seja mantido o padrão de vida do segurado - que não se contenta apenas com os mínimos vitais assegurados pelo regime público [...]" (SANTOS, 2015, p. 577).

Logo, "[...] é complementar (no sentido da suplementação facultativa dos benefícios), como determina o art. 202 da Constituição, e sendo facultativa, portanto, depende da manifestação de vontade das pessoas" (WEINTRAUB, 2003, p. 8).

Ademais, o regime de previdência complementar é facultativo, ou seja, fica a critério da pessoa aderir ao sistema, permanecer nele ou então dele retirarse. Dessa maneira, "[...] a previdência privada tem caráter facultativo, em que a manifestação de vontade é a principal característica. A natureza contratual lhes dá caráter eminentemente privado" (SANTOS, 2015, p. 579).

Nesse sentido, entende-se que "não há obrigatoriedade de adesão a plano de previdência privada. Tanto é assim que a legislação não utiliza o termo 'segurado', mas, sim, denomina 'participantes' [...]" (SANTOS, 2015, p. $579)$. 
Em relação à sua autonomia, "a previdência complementar privada é organizada de forma autônoma em relação ao RGPS. A inscrição de participante em plano de previdência complementar não o dispensa da inscrição como segurado obrigatório do RGPS [...]" (GOES, 2015, p. 744).

Ramos (2005, p. 69) também enfatiza que:

No regime complementar, os indivíduos protegidos são denominados participantes e têm a facultatividade de filiar-se ao sistema protetivo suplementar e de verter, de acordo com os estatutos de cada plano de benefícios, contribuições mensais, únicas ou esporádicas ao sistema.

Além disso, o vínculo que existe entre os participantes (contratante pessoa física que adere ao plano de benefícios), instituidores, patrocinadores e as entidades de previdência complementar é firmado através de um contrato. Portanto, "a contratualidade é a característica ligada à formalização material dos direitos e obrigações do participante de entidade de Previdência Privada" (WEINTRAUB, 2003, p. 9).

Tem-se assim que, "a Previdência Complementar tem natureza contratual. O regulamento de um plano de previdência é um contrato, que contém cláusulas sobre contribuições, benefícios e períodos de carência, entre outras disposições [...]" (GOES, 2015, p. 744).

Já, em relação aos beneficiários dos planos de previdência complementar têm-se os participantes e os assistidos. "[...] De acordo com o art. $8^{\circ}$ da LC 109/01, considera-se: (I) participante, a pessoa física que aderir aos planos de benefícios; e (II) assistido, o participante ou seu beneficiário em gozo de benefício de prestação continuada" (GOES, 2015, p. 752).

Em um contexto geral sobre o assunto, ainda é importante destacar que "os planos de previdência devem constituir reservas técnicas que lhes garantam a solvência, isto é, o pagamento dos benefícios contratados. O equilíbrio financeiro e atuarial deve estar garantido" (SANTOS, 2015, p. 580).

Por fim, é de se dizer que a Lei Complementar 109, de 29 de maio de 2001 é que regulamenta o regime de previdência complementar, ademais "[...] esta lei complementar assegura ao participante de planos de benefícios de entidades de previdência privada o pleno acesso às informações relativas à gestão de seus respectivos planos [...]" (GOES, 2015, p. 744).

\subsection{Entidades Abertas e Fechadas de Previdência Complementar Privada}

Conforme o artigo $4^{\circ}$ da Lei Complementar 109 do ano de 2001, as entidades de previdência complementar privada são classificadas em abertas e fechadas. 
Assim, primeiramente impende informar que "[...] os planos de Previdência Privada aberta são relativamente mais flexíveis do que os planos de Previdência Privada fechada, apesar do caráter contratual de ambos" (WEINTRAUB, 2003, p. 07).

As entidades de previdência complementar aberta estão regulamentadas no artigo 36 da Lei Complementar $n^{\circ}$ 109/2001 e são denominadas desta maneira, pois podem "[...] oferecer seus planos de benefícios a qualquer pessoa interessada. Vale dizer, qualquer pessoa física pode aderir a um plano de previdência complementar aberta, independentemente de vínculo profissional ou associativo" (GOES, 2015, p. 750).

Complementando tais ensinamentos, Goes $(2015$, p. 21) afirma que:

[...] são constituídas unicamente sob a forma de sociedades anônimas e têm por objetivo instituir e operar planos de benefícios de caráter previdenciário concedidos em forma de renda continuada ou pagamento único, acessíveis a quaisquer pessoas físicas (LC 109/2001, art. 36).

Ademais, "[...] a filiação de participantes aos planos de benefícios dessas entidades não depende da existência de qualquer vínculo prévio entre as pessoas físicas e/ou jurídicas envolvidas na relação de previdência complementar [...]" (RAMOS, 2005, p. 41).

Destaca-se ainda que as "[...] entidades abertas são custeadas exclusivamente com aportes do trabalhador participante (cotização individual)" (CASTRO; LAZZARI, 2014, p. 107).

Já em relação às entidades de previdência fechada informa-se que "contrariamente à possibilidade de livre acesso de participantes aos planos de benefícios das entidades abertas, é restrito o ingresso de participantes nos planos geridos pelas entidades fechadas de previdência complementar [...]" (RAMOS, 2005, p. 44).

Ademais, sobre o assunto, Goes (2015, p. 21) destaca que:

De acordo com o art. 31 da Lei Complementar 109/2001, as entidades fechadas são aquelas acessíveis, na forma regulamentada pelo órgão regulador e fiscalizador, exclusivamente:

I. aos empregados de uma empresa ou grupo de empresas e aos servidores da União, dos Estados, do Distrito Federal e dos municípios, entes denominados patrocinadores; e

II. aos associados ou membros de pessoas jurídicas de caráter profissional, classista ou setorial, denominadas instituidores.

Portanto, "os planos de benefícios oferecidos pelas entidades fechadas somente são acessíveis aos empregados das patrocinadoras e aos associados ou 
membros das instituidoras, sem qualquer restrição, com exceção dos planos em extinção [...]" (RAMOS, 2005, p. 44).

Além disso, as entidades fechadas de previdência privada "[...] são conhecidas como 'fundos de pensão', criados entre uma ou mais empresas de um mesmo grupo econômico, para seus funcionários" (WEINTRAUB, 2003, p. 7).

Goes (2015) ainda informa que, conforme disposto no artigo 31, parágrafo $1^{\circ}$ da Lei Complementar 109 de 2001, as entidades fechadas deverão se organizar sob forma de sociedade civil sem fins lucrativos ou de fundação.

Nesta senda, verifica-se que "[...] não pode o próprio empregador explorar a atividade de previdência complementar; para estabelecer o plano previdenciário privado, deverá constituir entidade própria para este fim" (CASTRO; LAZZARI, 2014, p. 106).

Já em relação ao custeio dos planos de previdência complementar de entidades fechadas é de se dizer que "[...] será feito por meio de contribuições dos participantes (trabalhadores que aderirem), dos assistidos (dependentes de trabalhadores que possam aderir também ao plano) e do patrocinador (empregador)" (CASTRO; LAZZARI, 2014, p. 107).

Por fim, na entidade de previdência complementar fechada "[...] os planos de benefícios devem ser, obrigatoriamente, oferecidos a todos os empregados dos patrocinadores ou associados dos instituidores (LC 109, art. 16). Mas a adesão do participante é sempre facultativa (LC, 109, art. 16, $\left.\S 2^{\circ}\right)^{\prime \prime}$ (GOES, 2015, p. 22).

\section{FUNÇÃO E IMPORTÂNCIA DA PREVIDÊNCIA COMPLEMENTAR PRIVADA}

Tendo em vista que, na atualidade, há por parte das pessoas uma grande preocupação quanto ao futuro, principalmente pelas diversas alterações legislativas, e, baseados na ideia de que a previdência pública não concederá nem a si, nem a seus familiares, mais do que benefícios básicos, as mesmas estão buscando através da previdência complementar privada uma forma de segurança e, por isso, é de extrema importância elencar, no presente trabalho, quais os principais objetivos que este tipo de previdência busca alcançar.

Conforme Póvoas (2007), a grande preocupação do homem na atualidade é com a segurança do futuro. Ademais, as diversas instituições que hoje existem e que deveriam cuidar do bem-estar das pessoas, acabam deixando a desejar, fazendo com que as mesmas busquem outras alternativas, novos esquemas socioeconômicos, especialmente na área previdenciária.

É de se dizer que "em face de uma pretensa inviabilidade de a previdência pública arcar futuramente com os gastos necessários à sua sobrevivência, 
muitos países buscam solução com a previdência privada [...]" (CORREIA; CORREIA, 2013, p. 43).

Assim, "o mundo começa a considerar o papel que está reservado à previdência, face às dificuldades que os sistemas de segurança social experimentam, agravados dia-a-dia pela multidão dos que são atingidos pelos riscos sociais [...]" (PÓVOAS, 2007, p. 32).

Portanto, “a sociedade organiza-se em entidades de previdência privada, bem como incentiva o seu desenvolvimento, de forma a garantir maior segurança econômica e social aos integrantes dos planos de benefícios dessas entidades" (RAMOS, 2005, p. 23).

Póvoas (2007) enfatiza que apesar de os sistemas previdenciários serem cada vez mais abrangentes, estão, em contrapartida, cada vez mais exigentes no que se refere a contribuições, e, por isso, "[...] nunca lhe concederão, nem à sua família, mais do que benefícios básicos em caso de doença, de inatividade ou morte [...]" (PÓVOAS, 2007, p. 30).

Logo, sobre os objetivos da previdência privada, resta evidenciado que:

A previdência privada nasceu com a finalidade de garantir mais proteção à sociedade. Visa ao seu desenvolvimento econômico e social, por meio da capitalização de seus recursos, buscando o desenvolvimento econômico e, consequentemente, a melhoria da qualidade de vida de todos os cidadãos (RAMOS, 2005, p. 23).

Ademais, a previdência privada, "[...] busca também alcançar sua função primordial de garantir tranquilidade social e manutenção do padrão de vida de seus participantes e assistidos [...]" (RAMOS, 2005, p. 24).

Conclui-se, portanto, que o principal objetivo dos planos de previdência privada é de "[...] permitir uma continuidade no padrão de vida da pessoa, numa fase madura da vida, complementando uma aposentadoria oficial" (WEINTRAUB, 2003, p. 6-7).

\section{CONCLUSÃO}

O presente estudo, mesmo que de forma sucinta, preocupou-se em, um primeiro momento, realizar o levantamento sobre a origem da seguridade e da previdência social no Brasil e também da previdência complementar, pois, através destes aspectos, se observou as conquistas previdenciárias alcançadas no decorrer do tempo, bem como as diversas alterações ocorridas na legislação.

Ademais, considerou-se extremamente importante trazer o conceito e as principais características da previdência complementar privada, pois se acredita que tendo tais pontos bem esclarecidos, a compreensão do tema seja facilitada. 
Abordou-se sobre a função da previdência complementar privada, chegando-se ao entendimento de que a mesma é importante, uma vez que se tem o consenso de que a previdência pública não concederá às pessoas mais do que benefícios básicos. No entanto, infelizmente nem todas as pessoas possuem condições financeiras de poder contratar um plano de previdência complementar para garantir não só a sua tranquilidade financeira, como a de sua família, permanecendo então atrelados à previdência pública.

Assim, a previdência pública, apesar de estar longe de ser o meio de sustento ideal, é, muitas vezes, a única fonte de renda de uma família. Sabese, no entanto, que, nos moldes atuais, vem sendo alvo de muitas críticas, principalmente por parte do governo, que, conforme abordado no presente trabalho, encaminhou proposta de reforma da previdência, pois afirma que ela é a grande responsável pelo rombo dos cofres públicos.

Em contrapartida, se esta proposta for aprovada, haverá um grave retrocesso aos direitos e garantias que foram conquistados pelos cidadãos no decorrer dos anos, afrontando até mesmo princípios garantidos pela Constituição de 1988. Se aprovada a reforma previdenciária, da forma como tem sido proposta, a previdência complementar assumirá papel de maior visibilidade.

Assim, conclui-se que apesar de a previdência complementar privada não ser obrigatória, ela se apresenta como uma alternativa para o cidadão que possui condições financeiras de complementar seus rendimentos, no sentido de buscar tranquilidade para o seu futuro e de sua família. Nesse sentido, o trabalho buscou contribuir com esclarecimentos essenciais àqueles que pretendem conhecer melhor esta forma de previdência.

\section{REFERÊNCIAS}

ARALDI JUNIOR, João Irineu. A participação social como forma de implementar o estado democrático de direito brasileiro. In: ÂMBITO Jurídico, Rio Grande, XIII, n. 79, ago 2010. Disponível em: <http:/ / www.ambito-juridico.com.br/site/?n_link=revista_ artigos_leitura\&artigo_id=8206>. Acesso em: 06 fev. 2017.

BRASIL. Câmara dos Deputados. Projetos de Lei e outras Proposições. 2017. Disponível em: <http:/ /www.camara.gov.br/proposicoesWeb/ fichadetramitacao?idProposicao=211988>. Acesso em: 20 fev. 2017.

. Constituição (1988). Constituição da República Federativa do Brasil.

Disponível em: <http://www.planalto.gov.br/ccivil_03/constituicao/constituicao. htm>. Acesso em: 01 set. 2016.

. Decreto $\mathrm{n}^{\circ} 4.682$, de 24 de janeiro de 1923. Disponível em: http:/ /www. planalto.gov.br/ccivil_03/decreto/Historicos/DPL/DPL4682.htm. Acesso em: 01 set. 2016. 
Lei Complementar 109, de 29 de maio de 2001. Disponível em: <http:/ /www. planalto.gov.br/ccivil_03/leis/lcp/lcp109.htm>. Acesso em: 16 set. 2016.

CASTRO, Carlos Alberto Pereira de; LAZZARI, João Batista. Manual de Direito Previdenciário. 16. ed. Rio de Janeiro: Forense, 2014.

CORREIA, Marcus Orione Gonçalves; CORREIA, Érica Paula Barcha. Curso de Direito da Seguridade Social. 7. ed. São Paulo: Saraiva, 2013.

CORREIA, Marcus Orione Gonçalves; VILLELA, José Corrêa. Previdência Privada: doutrina e comentários à lei complementar n. 109/01. São Paulo: LTr, 2004.

GOES, Hugo. Manual de Direito Previdenciário. Rio de Janeiro: Ferreira, 2015.

LEITE, Carlos Henrique Bezerra. Direitos Humanos. 2. ed. Rio de Janeiro: Lumen Juris, 2011.

LIMA, Salomão Loureiro de Barros. Breves linhas sobre o histórico do direito previdenciário no Brasil. DireitoNet., 23 out. 2013. Disponível em: <http:/ / www. direitonet.com.br/artigos/exibir/8160/Breves-linhas-sobre-o-historico-do-direitoprevidenciario-no-Brasil>. Acesso em: 01 set. 2016.

MARTINS, Sergio Pinto. Direito da Seguridade Social. 21. ed. São Paulo: Atlas, 2004.

MORAIS, Jose Luis Bolzan de. Do Direito social aos interesses transindividuais: o Estado e o direito na ordem contemporânea. Porto Alegre: Livraria do Advogado, 1996.

PÓVOAS, Manuel Sebastião Soares. Previdência Privada. Filosofia, Fundamentos Técnicos, Conceituação Jurídica. São Paulo: Quartier Latin, 2007.

RAMOS, Maria Cibele de Oliveira. Os Planos de Benefícios das Entidades de Previdência Privada. São Paulo: LTr, 2005.

SANTOS, Marisa Ferreira dos. Direito Previdenciário Esquematizado. São Paulo: Saraiva, 2015.

Direito Previdenciário. São Paulo: Saraiva, 2016.

SARLET, Ingo Wolfgang. A eficácia dos direitos fundamentais: uma teoria geral dos direitos fundamentais na perspectiva constitucional. Porto Alegre: Livraria do Advogado, 2009.

SILVA, Luzia Gomes da. Seguridade Social: das origens e conceito aos princípios que sustentam o Estado Democrático do Direito. In: ÂMBITO Jurídico, Rio Grande, XV, n. 99, abr. 2012. Disponível em: <http:/ / www.ambito-juridico.com.br/site/?n_ link=revista_artigos_leitura\&artigo_id=11417>. Acesso em: 01 set. 2016. 
TAVARES, Marcelo Leonardo. Direito Previdenciário. Rio de Janeiro: Lumen Juris, 2005.

WEINTRAUB, Arthur Bragança de Vasconcellos. Previdência Privada: atual conjuntura e sua função complementar ao Regime Geral da Previdência Social. São Paulo: Juarez de Oliveira, 2003. 